\title{
Treatment with Hydroxychloroquine vs Hydroxychloroquine + Nitazoxanide in COVID-19 patients with risk factors for poor prognosis: A structured summary of a study protocol for a randomised controlled trial
}

José Meneses Calderón ${ }^{1,2}$, Hugo Mendieta Zerón ${ }^{3,4,5^{*}+}$ (1) and Srivatsan Padmanabhan ${ }^{6+}$

\begin{abstract}
Objectives: To determine the efficacy of Hydroxychloroquine vs. Hydroxychloroquine + Nitazoxanide in reducing the need for invasive mechanical ventilatory support for patients with COVID-19. Hydroxychloroquine is currently being used in multiple trials with varying doses in an attempt to treat COVID-19. Nitazoxanide has powerful antiviral effects and proven efficacy against a range of viruses including SARS and MERS. Dual therapy by combining appropriate doses of these two medications with diverse activities against COVID-19 is expected to be better than monotherapy with hydroxychloroquine.

Trial design: This is a single centre, randomized, controlled, single blinded, 2 arm (ratio 1:1) parallel group trial. Participants: 86 COVID-19 positive patients that are being treated at the Health Institute of the State of Mexico (ISEM) in Toluca, State of Mexico will be recruited from May 14 to December 31, 2020.

Inclusion criteria:

1) Age older than 18 years.

2) Hospitalised COVID-19 PCR test positive patients.

3) Within the first 72 hours after performing the PCR test.

4) Presence of risk factors for complications (at least one): over 60 years, history of diabetes mellitus,

hypertension, and morbid obesity.
\end{abstract}

(Continued on next page)

\footnotetext{
* Correspondence: hmendietaz@uaemex.mx

+Hugo Mendieta Zerón and Srivatsan Padmanabhan contributed equally to this work.

${ }^{3}$ Autonomous University of the State of Mexico (UAEMex), Internal Medicine and Medical Sciences (UNAM), Endocrinology, University of Santiago de

Compostela, Santiago de Compostela, Spain

${ }^{4}$ Faculty of Medicine, UAEMéx, Toluca, Mexico

Full list of author information is available at the end of the article
}

(c) The Author(s). 2020 Open Access This article is licensed under a Creative Commons Attribution 4.0 International License, which permits use, sharing, adaptation, distribution and reproduction in any medium or format, as long as you give appropriate credit to the original author(s) and the source, provide a link to the Creative Commons licence, and indicate if changes were made. The images or other third party material in this article are included in the article's Creative Commons licence, unless indicated otherwise in a credit line to the material. If material is not included in the article's Creative Commons licence and your intended use is not permitted by statutory regulation or exceeds the permitted use, you will need to obtain permission directly from the copyright holder. To view a copy of this licence, visit http://creativecommons.org/licenses/by/4.0/ The Creative Commons Public Domain Dedication waiver (http://creativecommons.org/publicdomain/zero/1.0/) applies to the data made available in this article, unless otherwise stated in a credit line to the data. 
(Continued from previous page)

Exclusion criteria:

1) Patients with corrected QT interval (QTc) greater than $500 \mathrm{~ms}$ at hospital admission.

2) Patients who have inherent contraindications to each drug.

3) Patients who are unable to consent.

4) Patients who have previously received chloroquine.

5) Patients already intubated.

Elimination criteria:

1) Patients whose clinical follow-up is lost or who decide not to continue in the study

Intervention and comparator: The two management alternatives will be:

Control - Hydroxychloroquine 200 mg taken orally every 12 hours for 7 days.

Dual therapy - Hydroxychloroquine 400 mg taken orally every 12 hours for two days and then 200 mg taken orally every 12 hours for four days + Nitazoxanide 500 mg orally every 6 hours taken with food, for seven days.

Main outcomes: Primary: Mechanical ventilation requirement assessed at one week.

Percentage of COVID-19 positive patients who require mechanical ventilation. All patients will be monitored till hospital discharge or death.

Randomisation: Patients will be randomly allocated using allocation papers and opaque sealed envelopes to either receive the placebo or the dual therapy intervention treatment in a 1:1 ratio until we have recruited the required number of patients for each group.

Blinding (masking): Trial participants will be blinded.

Numbers to be randomised (sample size): 86 participants will be randomized to each group, with 43 in the control group and 43 in the dual therapy group.

Trial Status: Protocol version: 2, recruitment will begin on May 14 until sample size is reached, with the analysis deadline of December 31st 2020.

Trial registration: ClinicalTrials.gov Identifier: NCT04341493.

Date of trial registration: April 10, 2020

Full protocol: The full protocol is attached as an additional file, accessible from the Trials website (Additional file 1). In the interest of expediting dissemination of this material, the familiar formatting has been eliminated; this Letter serves as a summary of the key elements of the full protocol

Keywords: COVID-19, Randomised controlled trial, protocol, Dual therapy, hydroxychloroquine, nitazoxanide, SARS-COV-2, treatment regimen

\section{Supplementary information}

Supplementary information accompanies this paper at https://doi.org/10. 1186/s13063-020-04448-2

Additional file 1. Full study protocol.

\section{Acknowledgements}

Not applicable.

\section{Authors' contributions}

JMC: Chief Investigator; he conceived the study, conceptualization, literature review. HMZ: writing of the protocol, logistics and writing this summary. SP: contributed to study design, to development of the proposal and writing this summary. All authors read and approved the final manuscript.

\section{Funding}

This study has no specific funding source to declare other than conducted as part of the medical care in the study site.

\section{Availability of data and materials}

The three researchers will have access to the final trial dataset. There are no contractual agreements that limit such access for investigators and will be available on request.

Ethics approval and consent to participate

This project has been authorized (code 2020-03-681) by the Research Ethics Committee of the "Mónica Pretelini Sáenz" Maternal-Perinatal Hospital (HMPMPS), with current registration with the National Bioethics Commission (CONBIOETICA) as well as by the Research Committee of the same Hospital with current registration in the Federal Commission for the Protection against Health Risks (COFEPRIS). It has also been approved by the Research Ethics Committee of the General Hospital of Mexico "Dr. Eduardo Liceaga". The research will be carried out under the ethical considerations recognized by the Declaration of Helsinki (Fortaleza, Brazil, 2013), and according to the level of intervention, it is considered a study of greater than minimum risk. Written, informed consent to participate will be obtained from all participants. 


\section{Consent for publication}

Not applicable.

\section{Competing interests}

The authors declare that they have no competing interests.

\section{Author details}

'Internal Medicine, Intensive Care Unit, "Lic. Adolfo López Mateos" General Hospital, Toluca, Mexico. ${ }^{2 " M o ́ n i c a ~ P r e t e l i n i ~ S a ́ e n z " ~ M a t e r n a l-P e r i n a t a l ~}$ Hospital, Toluca, Mexico. ${ }^{3}$ Autonomous University of the State of Mexico (UAEMex), Internal Medicine and Medical Sciences (UNAM), Endocrinology,

University of Santiago de Compostela, Santiago de Compostela, Spain.

${ }^{4}$ Faculty of Medicine, UAEMéx, Toluca, Mexico. ${ }^{5}$ Research Department

"Mónica Pretelini Sáenz" Maternal-Perinatal Hospital, Toluca, Mexico. 'Internal Medicine, St. Joseph Medical Center, Tacoma, WA, USA.

Received: 20 May 2020 Accepted: 23 May 2020

Published online: 08 June 2020

\section{Publisher's Note}

Springer Nature remains neutral with regard to jurisdictional claims in published maps and institutional affiliations.

Ready to submit your research? Choose BMC and benefit from:

- fast, convenient online submission

- thorough peer review by experienced researchers in your field

- rapid publication on acceptance

- support for research data, including large and complex data types

- gold Open Access which fosters wider collaboration and increased citations

- maximum visibility for your research: over $100 \mathrm{M}$ website views per year

At $B M C$, research is always in progress. 